\title{
Menelusuri Nilai Budaya Yang Terkandung Dalam Pertunjukan Tradisional Wayang
}

\author{
R. Jatinurcahyo ${ }^{1)}$, Yulianto2) \\ Program Studi Perhotelan Universitas Bina Sarana Informatika \\ Jalan Ring Road Barat, Ambarketawang, Gamping, Sleman Yogyakarta \\ E-mail : r.jno@bsi.ac.id ${ }^{1)}$, yulianto.ylt@ac.id(2)
}

\begin{abstract}
Abstrak
Wayang adalah salah satu jenis kebudayaan Indonesia yang sampai saat ini masih eksis karena didalamnya mengandung nilai-nilai positif dan memberikan tambahan wawasan pada setiap pertunjukan dari tokoh yang diperankannya, meskipun dalam rentang waktu dan perkembangan, Masih kurang minat masyarakat utamanya genarasi mudah mempelajari dan menghayati, mendalami seni wayang untuk dipertunjukan ke masyarakat, bahkan seni budaya pertunjukan tradisional wayang ini secara dinamis berkembang mengikuti kemajuan zaman dengan berbagai variasi pertunjukan . Tujuan penelitian untuk mengetahui nilai-nilai apa saja yang terkandung dalam setiap cerita pertunjukkan tradisional wayang. Metode penelitian menggunakan analisis kualitatif dengan pendekatan etnografi. Teknik pengumpulan data dengan wawancara, studi pustaka, pengamatan langsung dan dokumentasi berupa data informan atau nara sumber yaitu Ki Hadi Sutoyo. Hasil penelitian menemukan terdapat nilai-nilai budaya yang terkandung dalam pertunjukkan tradisional wayang yaitu Nilai Religius, Nilai Pendidikan, Nilai Kebangsaan dan Nilai Kepemimpinan.
\end{abstract}

Kata Kunci : Nilai Budaya, Wayang, Pertunjukan

\section{Explore Cultural Values Contained In Wayang Traditional Show}

\begin{abstract}
Puppet is one of the Indonesian culture which still exists up to present because it reflects positive values and gives additional knowledge from the characters in its stage performances. From time to time, puppet traditional stage art dynamically changes depending on the actual contexts follows within. There is still a lack of interest from the community, especially the generation that is easy to learn and appreciate, deepening the art of wayang to be show to the public, even this traditional cultural art of wayang performance is dynamically developing following the times with various variation of performances. The data collection techniques are by interviews, literature reviews, direct observation, and documentations data the main source Ki Hadi Sutoyo. Result of the research finds out that the cultural values in the puppet traditional arts are religious value, education value, national value, and leadership value.
\end{abstract}

Keywords: Cultural Values, Puppet, Show

\section{PENDAHULUAN}

Kebudayaan merupakan sistem makna melalui berbagai simbol atau gambaran mengandung Nilai-Nilai Budaya tertentu yang perlu untuk dibaca ditangkap dan ditafsirkan untuk selanjutnya dapat dimengerti dan dipahami oleh masyarakat serta diwariskan pada generasi penerus. Segala perilaku, tindakan, perbuatan ataupun peristiwaperistiwa tertentu yang melingkupi hidup masyarakat kerap kali dikaitkan dengan simbol atau gambaran dan makna tertentu yang dihubungkan dengan kondisi masyarakatnya.
Budaya tradisional wayang pada hakekatnya mempunyai peran sebagai sarana komunikasi yang tumbuh dan perkembangannya berjalan dinamis bersamaan dengan situasi dan kondisi dari masyarakat yang mampu menunjukkan eksistensinya. Liliweri (2014) mengemukakan bahwa budaya tradisional menggambarkan suatu keyakinan dan praktek dari sekelompok orang tertentu yang mereka warisi dari nenek moyang atau orang tua dan lingkungan mereka. Seperti halnya bentuk kesenian tradisional lain, masing-masing memiliki ciri khusus yang sesuai dengan keadaan dari komunitas masyarakat pendukungnya dan 
yang melatarbelakangi keberadaan kesenian tradisional tersebut. Seni hadir sebagai unsur kebudayaan yang mengekspresikan dan merefleksikan dalam penyampaian tuntunan dan tanggapan dari masyarakat terhadap perkembangan lingkungannya.

Salah satu bentuk dari seni budaya tradisional yang mampu mengungkapkan nilainilai kehidupan dalam bermasyarakat yaitu seni pertunjukkan wayang. Dimana pesan kepada masyarakat yang sejalan dengan nilai-nilai universal yang terdapat di masyarakat tersebut. Pesan yang diekspresikan dalam bentuk karya seni merupakan refleksi dan sarana komunikasi yang tepat agar membudaya di masyarakat didalam mengembangkan kepribadian bangsa yang didasarkan pada Nilai-Nilai Moral.

Dikarenakan nilai budaya pada wayang mempunyai peran yang sangat vital dalam menumbuhkan dan mengembangkan kepribadian bangsa, maka lakon yang diperankan oleh tokoh-tokoh pada cerita pertunjukkan wayang harus mengekspresikan dan menggambarkan kehidupan masyarakat yang sebenarnya. Yang mana masyarakat dapat terpengaruhi sikap dan perilakunya untuk mengaktualisasikan nilai-nilai yang ada pada kehidupan masyarakat.

Pengertian kebudayaan menurut Kamus Besar Bahasa Indonesia (KBBI) adalah hasil kegiatan dan penciptaan batin (akal budi) manusia seperti kepercayaan, kesenian dan adat istiadat. Diartikan pula yaitu keseluruhan pengetahuan manusia sebagai makhluk sosial yang digunakan untuk memahami lingkungan serta pengetahuannya yang menjadi pedoman tingkah lakunya (antropologi).

$$
\text { Manusia beradaptasi dalam }
$$

lingkungannya melalui medium kebudayaan. Nilai-nilai budaya terbentuk karena terjadinya proses adaptif antara manusia dengan lingkungannya yang dipandang sesuai dan bermanfaat untuk kehidupannya di masyarakat.

Nilai-nilai budaya dalam kebudayaan memiliki fungsi penting karena didalamnya memuat aturan tata krama perilaku manusia. $\mathrm{Hal}$ ini sejalan dengan yang dikemukakan oleh Koentjaraningrat dalam Damarjati (2015) bahwa Nilai Budaya biasanya juga berfungsi sebagai tata kelakukan yang mengatur, mengendalikan dan memberi arah keda kelakuan dan perbuatan manusia dalam masyarakat.

Masyarakat utama generasi muda dapat menjadi generasi penerus mencintai, menghayati, mendalami dan mengimplementasikan seni budaya pertunjukan wayang yang selalu dapat mengikuti perubahan zaman dengan berbagai macam inovasi pada saat pertunjukan ditampilkan.

\section{TINJAUAN PUSTAKA}

\section{Nilai Budaya}

Liliweri (2014) menjelaskan Nilai merupakan salah satu unsur dasar pembentukan orientasi budaya, nilai melibatkan konsep budaya yang menganggap sesuatu itu sebagai baik atau buruk, benar atau salah, adil atau tidak adil dan sebagainya. Nilai berupa norma aturan yang digunakan sebagai acuan dalam manusia melakukan tindakan. Fungsi dari pada Nilai untuk motivator, sedangkan manusia sebagai yang mendukung Nilai. Dimana manusia dalam bertindak karena ada dorongan dari Nilai yang diyakininya. Budaya diartikan oleh Koentjaraningrat dalam Damarjati (2015) merupakan sebuah sistem gagasan dan rasa, sebuah tindakan serta karya yang dihasilkan oleh manusia didalam kehidupannya yang bermasyarakat, yang dijadikan kepemilikannya dengan belajar.

Nilai budaya yang dimaknai sebagai acuan, pengharapan masyarakat dan tindakan yang dipandang masyarakat untuk dapat mentaati serta mematuhi norma aturan yang lebih baik dalam penerapan dan pelaksanaannya harus disertai dengan langkah evaluative untuk menjaga agar Nilai selalu diposisi yang harmoni. Ketidakharmonisan hubungan yang ada dalam masyarakat bersumber pada bagaimana kondisi Nilai Budaya yang ada. Oleh karena itu, Nilai Budaya masyarakat sangat menentukan arah terhadap Nilai mereka sendiri disaat melakukan interaksi dengan lingkungannya.

\section{Wayang}

Wayang menurut Suyami (2016) merupakan refleksi dari budaya Jawa, dalam arti pencerminan dari kenyataan kehidupan, nilai dan tujuan kehidupan, moralitas, harapan dan cita-cita kehidupan orang Jawa. Sementara itu, Jati (2018) menyatakan wayang adalah simbol dari hidup dan kehidupan manusia. Dalam hal ini cerita wayang pada setiap pertunjukkan tradisional terdapat Nilai-nilai luhur yang berguna untuk masyarakat karena dapat mengetahui gambaran kehidupan manusia dan harus bagaimana hidup ini dilakukan oleh manusia. 
Suyami (2016) lebih lanjut menjelaskan bahwa peraga dalam pertunjukkan tradisional wayang dapat dikelompokkan menjadi empat bagian yaitu : 1) Peraga Boneka, seperti : Wayang Golek, Wayang Kulit dan Wayang Klethik 2) Peraga Orang, seperti : Wayang Orang 3) Peraga Gambar, seperti : Wayang Beber dan 4) Tanpa Peraga, seperti : Wayang Kentrung dan Wayang Jemblung.

Berdasarkan keterangan Ki Hadi Sutoyo (informan) (2021) bahwa wayang yang berkembang saat ini merupakan perubahan bentuk wayang Hindu yang berkembang di Bali yang dikembangkan bentuknya oleh para Wali terutama oleh Sunan Kalijaga guna kepentingan Syiar agama Islam dengan memasukkan unsur-unsur dakwah yang selaras dengan tuntunan yang ada.

\section{METODE PENELITIAN}

Metode penelitian yang diterapakan adalah menggunakan metode deskriptif kualitatif yakni penelitian yang mendeskripsikan fakta-fakta yang mengemukakan gejalan secara lengkap dalam aspek yang diteliti, situasi dan kejadian.

Pengumpulan data yang digunakan pada penelitian ini adalah dengan metode kualitatif melalui pendekatan etnografi secara sistematis (Moleong, 2017) yaitu :

\section{Pengumpulan data wawancara}

Wawancara adalah percakapan dengan maksud tertentu. Percakapan dilakukan terhadap dua pihak, peneliti melakukan wawancara dengan pembicaraan informal dan pertanyaan secara spontanitas. Agar terwawancara mengetahui maksud dan wawancaranya, maka dilakukan wawancara baku terbuka. Adapun informan atau narasumber yang kompeten guna mendapatkan data pada penelitian ini adalah : Ki Hadi Sutoyo dari desa Bibis Kasihan Bantul sebagai Informan atau narasumber ini berprofesi sebagai dalang. Data dikumpulkan dengan wawancara terbuka. Data yang didapatkan berupa keterangan terhadap NilaiNilai Budaya yang terdapat pada tokoh-tokoh wayang.

\section{Pengumpulan data pengamatan}

Peneliti melakukan pengamatan secara langsung. Dimana observasi langsung dilakukan peneliti ke lapangan guna mengambil dan mencatat pada segala sesuatu yang berkenaan dengan wayang.

Pengumpulan data studi pustaka
Studi pustakan dilakukan guna mengumpulkan sumber informasi atas data yang ada berkenaan dengan wayang.

\section{Pengumpulan data studi Dokumentasi}

Dokumentasi yang digunakan adalah sumber data yang didapat dari narasumber berkaitan dengan wayang.

Analisa data menurut Moleong (2017) merupakan proses mengorganisasikan dan mengurutkan data ke dalam pola, kategori dan satuan uraian-uraian dasar sehingga dapat ditentukan tema dan dirumuskan hipotesa kerja seperti yang disarankan. Sedangkan Mitos dan Huberman dalam Moleong (2017) menyatakan bahwa Analisa data merupakan proses pengaturan urutan data, yaitu :

\section{Reduksi Data}

Reduksi data yaitu proses merangkum, memilih hal-hal yang pokok, memfokuskan pada hal-hal penting, dicarilah hal-hal terkait wayang. Dari data yang sudah direduksi dapat memberikan gambaran yang jelas dan memudahkan peneliti guna mengumpulkan data.

\section{Penyajian Data}

Data disajikan dalam bentuk uraian singkat dan dokumen dimana peneliti menyajikan data wayang dalam bentuk teks bersifat naratif.

\section{Penarikan Kesimpulan}

Kesimpulan awal bersifat sementara dan dapat berubah apabila ditemukan bukti kuat yang mendukung di tahap pengumpulan data selanjutnya. Jika kesimpulan ditahap awal didukung dengan bukti valid dan konsisten saat dilakukabn penelitian ulang di lapangan, maka kesimpulan tersebut kredibel dan belum pernah ada sebelumnya.

\section{HASIL DAN PEMBAHASAN}

Penghargaan dan pengakuan dari organisasi lembaga dunia PBB melalui UNESCO pada tanggal 7 Nopember 2003 terhadap kehidupan dan perkembangan wayang di Indonesia membuktikan bahwa pada seni wayang terkandung Nilai-Nilai Budaya yang sangat tinggi didalamnya. Hikmah yang dapatkan dalam kehidupan masyarakat diantaranya tumbuhnya Kembali bentuk-bentuk budaya lokal. Kekhawatiran pada masyarakat dan dijumpainya benturan-benturan batin secara tidak langsung menjadi media mawas diri, kesalahan apa yang telah dilakukan selama ini, perilaku yang seperti apa dan bagaimana harus dirubah dan dibenahi terhadap seni 
budaya tradisional. Adanya benturan-benturan batin yang dirasakan itulah pada akhirnya masyarakat mulai mencari semua jawaban atas budaya lokal yang melingkupi hidup mereka di kesehariannya. Lambat-laun masyarakat mulai mengenali kembali Nilai-Nilai Budaya lokal, yang tanpa disadari selama ini cenderung ditinggalkan oleh masyarakat. Yang mana justru Nilai-Nilai Budaya tersebut yang sebenarnya tanpa mereka sadari telah mengakar pada diri mereka.

Upaya mawas diri dari masyarakat tersebut untuk melihat kebelakang sebelum sesuatu terjadi guna memperbaiki diri pada kehidupan yang lebih baik untuk masa depan selanjutnya. Budaya eling lan waspada inilah yang kemudian mendorong seseorang untuk hidup seimbang dan selaras dalam hubungannya dengan sesama, dengan alam lingkungan tinggalnya serta dengan Sang Pencipta yaitu Tuhan Yang Maha Esa. Inilah sebenarnya tujuan yang dicapai pada simbol atau gambaran dari setiap cerita pertunjukan tradisional wayang.

Melalui budaya lokal masyarakat diajak kembali untuk berpijak pada tradisi, mengkaji ulang atas Nilai-Nilai Budaya yang selama ini menjadi kearifan lokal dan telah ada sejak leluhur nenek moyang kita. Ajaran Pendidikan yang mencerminkan kearifan lokal dapat ditemukan dalam kebudayaan Jawa. Cara berpikir, bertingkah laku dan bersikap dari suatu masyarakat disuatu daerah tertentu dimana terdapat Nilai-Nilai Budaya keluhuran budi beserta hal-hal kebaikannya yang secara obyektif sepantasnya untuk menjadi teladan merupakan kearifan lokal. Salah satu bentuk dari kearifan lokal dari masyarakat di Jawa adalah budaya pertunjukan tradisional wayang.

Nilai Budaya merupakan perangkat aturan yang menentukan sesuatu tindakan dinilai baik atau buruk dan bersifat abstraksi terhadap berbagai hal yang dianggap mempunyai makna dan memiliki Nilai Tinggi pada kehidupan masyarakat. Manusia diajarkan dan belajar menanamkan Nilai-Nilai Budaya dalam kepribadian dirinya. Melalui proses internalisasi mempengaruhi Nilai-Nilai Budaya suatu masyarakat tertanam dan menyatu pada kepribadian seseorang.

Wayang merupakan refleksi dari budaya suatu daerah yang memberikan gambaran pada kehidupan tentang bagaimana hidup yang sesungguhnya dan seperti apa hidup itu yang seharusnya dijalani. Cerita dan pertunjukkan tradisional wayang dan karakter dari tokoh- tokoh wayang menggambarkan Sebagian atas keadaan nyata dalam kehidupan di masyarakat. Dalam pertunjukkan tradisional wayang hal tersebut akan kelihatan jelas, dimana cerita apapun yang dimainkan pada setiap pertunjukkan akan mengkonfrontasikan antara dua golongan yaitu golongan ksatria dan golongan angkara murka. Dimana golongan ksatria akan mengedepankan akal pikiran rasional dan hati Nurani serta memposisikan sebagai penegak kebenaran dan bijaksana. Sementara itu, golongan angkara murka lebih mengutamakan pada Hasrat nafsu, kepuasan dan kekuasaan.

Oleh sebab itu, pada pertunjukkan tradisional wayang terkandung Nilai-Nilai yang sangat berguna dalam mengasah jiwa manusia dalam kehidupan bermasyarakat agar menjadi manusia yang mempunyai rasa kemanusiaan dan beradab. Dibutuhkan peran serta masyarakat dalam melestarikan budaya pertunjukan wayang ini. Wayang sendiri sebagai sebuah benda mati memerlukan perawatan yang baik agar bentuk dan sosok wayang tetap ada pada pakemnya. Strategi pemeliharaan dibutuhkan agar benda yang tersimpan tidak rusak ataupun dimakan serangga, sehingga keropos bahkan hancur menghilangkan jejak bentuk benda itu sendiri (Yulianto \& Wijayanti, 2020). Hal ini dapat berakibat tidak dapat dikenalinya lagi bentuk wayang sebagai karakter tokoh tertentu.

Dari berbagai cerita pertunjukan tradisional wayang yang berhasil kami teliti terkait Nilai-Nilai Budaya yang terkandung pada pertunjukan tradisional wayang yang diharapkan dapat mendukung kepariwisataan di Indonesia dan mempertebal penddiikan karakter bangsa Indonesia diantaranya sebagai berikut :

\section{Nilai Religius}

Dalam cerita pertunjukan tradisional wayang "Petruk dadi Ratu" bahwa Petruk sebenarnya hanyalah Punakawan dan sebagai Abdi dari golongan Ksatria. Namun demikian para tokoh Ksatria tidak ada yang protes karena sudah menjadi jalan cerita hidup manusia yaitu Urip mung saderma nglakoni, manungsa mung kinarya ringgit kang winayangake dening Hyang kang Murbeng Dumadi (Manusia hidup sekedar menjalani, sedangkan pula manusia hanya sebagai wayang yang dimainkan oleh Tuhan Yang Maha Pencipta). Maksudnya bahwa diatas dari kekuatan dan kekuasaan manusia masih terdapat kekuatan dan kekuasaan 
adikodrati yang mempunyai kekuasaan penuh dan menentukan nasib manusia yaitu Tuhan Yang Maha Pencipta.

Sumber : Tjahyadi (2021)

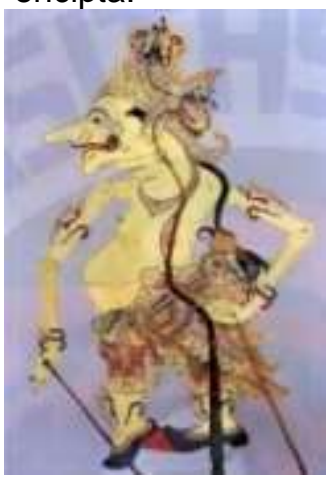

Gambar 1. Petruk dadi Ratu

Nilai religius yang terkandung dalam cerita wayang "Petruk dadi Ratu" bahwa manusia harus mempunyai kepercayaan untuk berserah diri kepada Sang Pencipta yaitu Tuhan Yang Maha Esa.

\section{Nilai Pendidikan Karakter}

Cerita pertunjukkan tradisional wayang yang mencerminkan Nilai-Nilai Pendidikan karakter dapat ditemukan dalam cerita wayang "Sumantri Ngenger". Mengisahkan tokoh Sumantri yang mengabdi kepada Raja Mahespati yang Bernama Prabu Arjuna Sasrabau. Untuk diterima menjadi Abdi, Sumantri harus memenuhi persyaratan yaitu harus mampu memboyong Dewi Citrawati yang dijadikan sayembara di Magada. Sumantri berhasil mengalahkan semua lawannya dan memboyong Dewi Citrawati yang kemudian dipersembahkan kepada Prabu Arjuna Sasrabau.

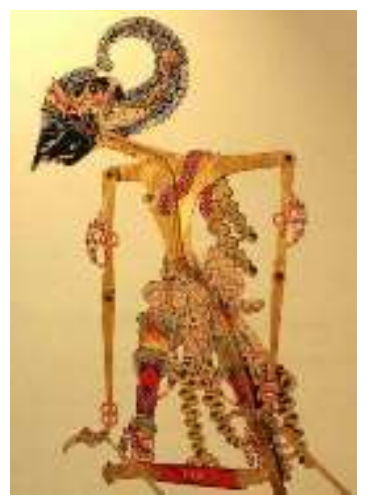

Sumber : Tjahyadi (2021) Gambar 2. Sumantri

Nilai Pendidikan yang terkandung dalam cerita wayang "2" yaitu terletak pada karakter tokoh Sumantri dalam konteks menanamkan loyalitas dan semangat etos kerja.

\section{Nilai Kebangsaan}

Keteguhan terhadap sikap dan prinsip hidup digambarkan pada cerita pertunjukkan tradisional wayang dengan cerita "Kumbakarna Gugur". Bahwa kecintaan Umbakarna kepada negara tercermin dengan keteguhan hatinya yaitu berani berkorban nyawa untuk kehormatan negara.

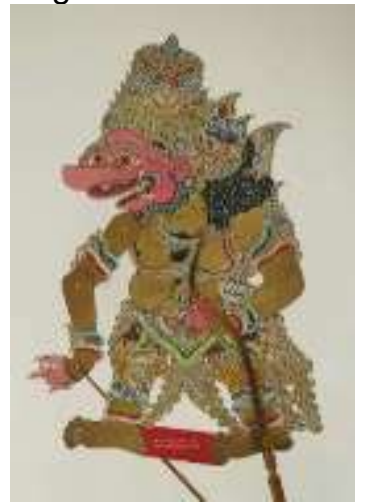

Sumber : Tjahyadi (2021)

Gambar 3. Kumbakarna

Nilai kebangsaan yang dapat ditemukan dalam cerita wayang "Kumbakarna Gugur" adalah jiwa nasionalisme.

\section{Nilai Kepemimpinan}

Asthabrata adalah ajaran kepemimpinan terdapat dalam cerita pertunjukkan tradisional wayang "Wahyu Makutha Rama", mensyaratkan bahwa seorang raja ideal harus memiliki delapan karakter utama yang berasal dari delapan dewa Lokapada atau Penjaga Alam Semesta yaitu Pemurah (Indra), Tegas dalam melaksanakan hukum (Yama), Bijakasana dan Halus dalam bertutur kata (Surya), Dermawan (Kuwera), Cerdas dan Cendekia (Baruna), Berani dan Bersemangat baja (Brama)

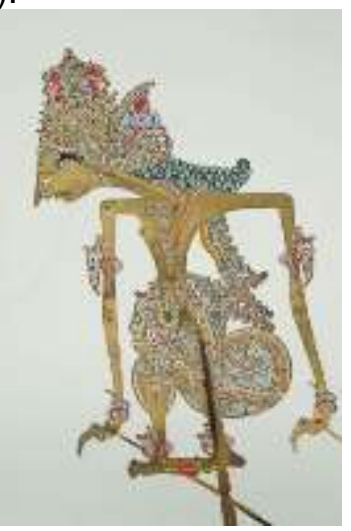

Sumber : Tjahyadi (2021)

$$
\text { Gambar 4. Rama }
$$

Tindakan sehari-hari mencerminkan keutamaan muncul karena wibawa seorang 
pemimpin tersebut yang tidak dimintakan dari orang-orang yang dipimpinnya. Dalam hal ini seorang pemimpin harus mendapatkan pengakuan tulus dan mandat dari rakyatnya, sehingga legitimasi seorang pemimpin akan teruji. Nilai kepemimpinan yang dapat diungkapkan dalam cerita wayang "Wahyu Makutha Rama" adalah Keteladanan dan Bijaksana.

\section{PENUTUP}

\section{Kesimpulan}

Seni budaya pertunjukan tradisional wayang yang memiliki Nilai-Nilai Budaya Adiluhung dan terbukti memberikan kontribusi terhadap kemajuan peradaban masyarakat sudah selayaknya untuk dilakukan pelestarian terlebih pada konteks Pendidikan. Memang tidak kita pungkiri bahwa segala sesuatu yang bernuasa tradisional bahwa kelangsungan dan kelestariannya kerap kali tergerus oleh arus budaya modern yang mengglobal. Namun demikian, fakta lain menunjukkan bahwa munculnya pemikiran dari masyarakat terhadap Nilai-Nilai Budaya yang mencerminkan kearifan budaya lokal mulai didorong dan ditumbuhkembangkan kembali guna menghadapi tantangan budaya baru yang dapat menghancurkan dan menghilangkan jatidiri dan peradaban dari suatu bangsa.

Dalam seni budaya pertunjukkan tradisional wayang mengandung tiga unsur yaitu sebagai tontonan dimana memiliki nilai seni dan keindahan, sebagai tuntunan karena dari cerita wayang yang ditampilkan terdapat ajaran-ajaran kehidupan dalam masyarakat dan sebagai tatanan yang memberikan dasar kesadaran bahwa kita hidup bermasyarakat tidak dapat dilepaskan oleh adanya tata krama dan tata etika.

Dalam pertunjukkan tradisional wayang dari hasil penelitian ditemukan Nilai-Nilai Budaya yang Adiluhung yaitu : (1).Nilai Religius bahwa setiap manusia harus mempunyai kepercayaan dan untuk selalu berserah diri kepada Sang Pencipta yaitu Tuhan Yang Maha Esa. (2).Nilai Pendidikan Karakter bahwa Pendidikan karakter dalam konteks menanamkan loyalitas dan semangat etos kerja harus diupayakan ditanamkan pada generasi muda. (3). Nilai Kebangsaan bahwa Nasionalisme berupa keteguhan hati untuk selalu mencintai Negara Kesatuan Republik Indonesia harus ada disetiap kalbu seluruh rakyat Indonesia. (4). Nilai Kepemimpinan bahwa sebagai salah seorang yang mendapatkan mandat oleh rakyat untuk memimpin, dalam dirinya harus mampu memberikan Keteladanan dan sikap Bijaksana.

\section{Saran}

Berdasarkan temuan dari hasil penelitian terhadap Nilai Budaya yang terkandung dalam pertunjukan tradisional wayang dan permasalahan yang ada pada seni pertunuukan disaat seperti ini perlu diberikan saran-saran sebagai berikut: (1). Dalam mempertahankan peradaban dan jatidiri bangsa sangat diperlukan peran pemerintah guna menggali lebih dalam lagi terhadap budaya berdasarkan kearifan lokal. (2). Perlunya pembinaan secara intensif dan berkesinambungan yang ditujukan pada generasi penerus agar selalu mencintai budaya asli Indonesia di masing-masing daerah. (3). Selalu menggalakkan pementasan pertunjukan tradisional wayang diberbagai upacara adat karena merupakan warisan budaya leluhur dimana sarat dengan Nilai-Nilai Budaya yang Adiluhung dan diharapkan dapat meningkatkan kunjungan pariwisata di Indonesia. (4). Adanya penghargaan dan pengakuan dari organisasi Lembaga dunia PBB melalui UNESCO pad atanggal 7 Nopember 2003 sudah sepantasnya menjadikan kebanggana dan tantangan untuk selalu dapat menjaga, mempertahankan dan mengembangkan Nilai-Nilai Budaya yang terkandung dalam wayang.

\section{DAFTAR PUSTAKA}

Damarjadi Kun, M. 2015. Nilai Budaya Yang Terkandung Dalam Tradisi Sasi Ikan Lompa. Jurnal PATRAWIDYA. Vol. 16 No. 3 Hal. 121-129. ISSN 1411-5239. Yogyakarta 2015.

Jati, N. 2018. Makna Simbolis Tokoh Wayang Semar Dalam Kepemimpinan Jawa. Jurnal Media Wisata. Vol. 16 No. 2 Hal 1069-1076. ISSN 1693-5969. Yogyakarta.

Koentjaraningrat. 2003. Metode-Metode Penelitian Masyarakat. Jakarta : PT. Gramedia.

Liliweri, A. 2014. Pengantar Studi Kebudayaan. Bandung: Penerbit Nusa Media.

Moleong Lexy, J. 2017. Metode Penelitian Kualitatif. Cetakan ke-36. Bandung: PT. Remaja Rosdakarya Offset.

Suyami. 2016. Wayang Sebagai Tontonan, Tuntunan dan Tatanan. Jurnal Jantra. 
Vol. 1 No. 1 ISSN 1907-9605. Yogyakarta Juni 2016

Tjahyadi. DR Sindung. Foto Koleksi Wayang Kulit. Yogyakarta : Fakultas Filsafat UGM.

Yulianto, Atun \& Ani Wijayanti. 2020. Strategi Pemeliharaan Dan Pengembangan Fasilitas Wisata Bagi Kenyamanan
Pengunjung Pule Payung Yogyakarta, Jurnal Pariwisata Vol. 7 No.2 September 2020.

https://ejournal.bsi.ac.id/ejurnal/index.ph p/jp/article/view/8932

Website : https://kbbi.web.id/ 